\title{
Efektifitas Penerapan Cooperative Scrift Dalam Meningkatkan Kemampuan Memahami Bacaan Siswa Kelas V SD Negeri 17 Parepare
}

\author{
Abdul Halik ${ }^{1}$, Muhamad Asrul Sultan ${ }^{2}$, Zaid Zainal ${ }^{3}$ \\ 1,2,3Program Studi PGSD Fakultas Ilmu Pendidikan Universitas Negeri Makassar \\ 1abdul.halik@unm.ac.id \\ 2asrul.sultan@unm.ac.id \\ ${ }^{3}$ zaid.zainal@unm.ac.id
}

\begin{abstract}
ABSTRAK
Pada pembelajaran bahasa Indonesia Di Sekolah Dasar ada empat keterampilan yang perlu dikuasai murid yaitu keterampilan menyimak, keterampilan menulis, keterampilan membaca, dan keterampilan berbicara. Pada pembelajaran membaca, seringkali murid merasa jenuh dan tidak termotivasi dalam mempelajarinya.Berkaitan dengan pentingnya pembelajaran membaca pemahaman, diperlukan metode-metode yang dapat menumbuhkan motivasi dan minat siswa dalam kegiatan membaca pemahaman di sekolah. Pembelajaran membaca pemahaman sebaiknya dilakukan dengan metode pembelajaran yang tepat guna mencapai hasil belajar yang optimal. Penelitian ini bertujuan menguji efektivitas penggunaan metode cooperative Scrift, dalam meningkatkan kemampuan membaca pemahaman pada siswa kelas V SD Negeri 17 Parepare. Jenis penelitian ini adalah penelitian eksperimen dengan menggunakan desain one group pretestposttest. Variabel dalam penelitian ini adalah Metode Cooperative Script sebagai variabel bebas dan tingkat keterampilan membaca pemahaman sebagai variabel terikat. Sampel dalam penelitian ini adalah seluruh siswa kelas V SD Negeri 17 Parepare yang berjumlah 37 orang. Teknik pengumpulan data menggunakan tes kemampuan membaca pemahaman berbentuk tes objektif sebanyak 30 butir soal. Validitas instrumen yang digunakan adalah validitas isi. Uji reliabilitas dianalisis dengan menggunakan rumus koefisien alpha cronbach. Teknik analisis data dilakukan dengan menggunakan teknik uji-t dengan memperhatikan syarat normalitas dan homogenitas. Hasil penelitian menunjukkan bahwa skor rerata kemampuan membaca siswa sebelum dan sesudah perlakuan mengalami peningkatan, yakni dari 16,86 menjadi 24,06. Hasil analisis uji-t menunjukkan $t_{\text {hitung }}$ sebesar $-24,829$ dengan $\mathrm{db}=36$, dan nilai $\mathrm{p}$ sebesar 0,000. Nilai p lebih kecil dari taraf signifikansi sebesar 0,05. Dengan kata lain, metode Cooperative Script efektif digunakan dalam pembelajaran membaca pemahaman.
\end{abstract}

Kata Kunci: Metode Cooperative Script, membaca pemahaman

\section{PENDAHULUAN}

Sejak usia dini membaca sudah diperkenalkan secara perlahan-lahan oleh lingkungan, baik itu lingkungan keluarga maupun lingkungan sekolah setelah anak memasuki jenjang pendidikan formal. Sejalan dengan itu pemerintah telah mengeluarkan Permendikbud Nomor 23 Tahun 2015 tentang Penumbuhan Budi Pekerti, Pusat Pembinaan, Badan Pengembangan dan Pembinaan Bahasa (Badan Bahasa), Kementerian Pendidikan dan Kebudayaan mempunyai program unggulan bernama "Gerakan Literasi Bangsa (GLB)" yang bertujuan untuk menumbuhkan budi pekerti anak melalui budaya literasi (membaca dan menulis). Budaya Literasi Sekolah memiliki peran yang amat penting dalam menanamkan mebaca pada pada anak didik. Untuk itu, tiap sekolah tanpa terkecuali harus memberikan dukungan penuh terhadap pengembangan literasi. Di sekolah dengan budaya literasi yang tinggi, peserta didik akan cenderung lebih berhasil dan guru lebih bersemangat mengajar.

Keberhasilan belajar seorang murid akan sangat ditentukan oleh kemampuan

membacanya dalam memahami sebuah informasi. Selain itu, kegiatan membaca juga dapat menambah pengetahuan dan informasi, serta memudahkan seseorang dalam berkomunikasi. Nurgiyanto (2012) menengaskan bahwa "dalam dunia pendidikan aktivitas dan tugas membaca nerupakan suatu hal yang tidak dapat ditawar-tawar".

Kendala yang sering dialami siswa dalam membaca pemahaman adalah berasal dari dalam dan luar. Kendala dari dalam meliputi kemampuan lingguistik (kebahasaan), 
minat, motivasi dan kemahiran membaca, sedangkan factor dari luar biasanya meliputi kesulitan bahan bacaan dan kualitas lingkungan membaca (Zuchdi: 2013).

Kendala dari luar berupa lingkungan membaca dapat menyebabkan timbulnay kendala dari dalam, seperti kurangnya minat dan motivasi siswa untuk membaca. Oleh karena itu lingkungan sekolah khususnya guru perlu membuat suasana agar siswa termotivasi dan mau membaca. Motivasi dan kemauan membaca pada siswa biasanya tumbuh seiring dengan kemampuan mereka memahami bacaan yang ia baca. Guru dituntut menciptakan atau meggunakan model pembelajaran sehingga siswa mampu memahami apa yang ia baca sehingga motivasi siswa untuk membaca terus bertumbuh dan berkembang utamanya memahami bacaan pada pelajaran-pelajaran lain.

Beberapa metode mengajar dalam pembelajaran membaca yang sering digunakan, anatara lain Talking Stick, PreP, ECOLA dan Cooperative Script. Metode Talking Stick siswa didorong untuk mampu mengungkapkan pendapatnya. Metode PreP didesain untuk siswa yang kurang dapat menggunakan sistem belajar yang komprehensif. Metode ECOLA digunakan untuk memperluas penguasaan konsep dan mengintegrasikan membaca, menulis, berbicara, dan mendengarkan, Sedankam metode script, difokuskan pada pembelajaran membaca untuk pemahaman makna bacaan.

\section{Metode Cooperative Script} merupakan metode untuk meningkatkan minat membaca sekaligus meningkatkan pemahaman siswa terhadap suatu teks bacaan (Suprijono: 2012). Metode ini adalah sebuah metode bekerja berkelompok, kemudian kelompok secara lisan bergantian mengikhtisarkan bagian-bagian dari materi yang dipelajari. Keunggulan metode ini di antaranya adalah melatih ketelitian/kecermatan siswa, melatih kerja sama yang baik dalam kelompok ketika berdiskusi, melatih siswa untuk dapat menyampaikan penjelasan secara lisan dan runtut pada saat presentasi, serta melatih keberanian mengungkapkan kesalahan orang lain secara lisan. Selain itu, metode Cooperative Script akan membawa murid ke dalam suasana belajar yang aktif, kreatif, efektif, dan menyenangkan. Dikatakan demikian karena setiap anggota kelompok bekerja untuk kelompoknya, mengungkapkan ide-idenya, lebih berbekas pada ingatan murid, dan terjalin hubungan kerjasama setiap anggota kelompok.

Obseravasi awal yang dilakukan penulis pada kelas V SD Negeri 17 Parepare, dengan melihat proses pembelajaran yang berlangsung menunjukkan kurangnya motivasi siswa dalam belajar bahasa Indonesia khususnya mengenai bacaan. Hasil wawancara langsung dengan gurunya juga menunjukkan ketidaktahuan akan adanya metode cooperative scrift.

Berdasarkan kenyataan di atas maka penulis berniat menguji efektifitas pembelajaran Bahasa Indonesia pada pokok bahasan memahami bacaan dengan menggunakan metode cooperative scrift.Bedasarkan latar belakang masalah di atas maka dirumuskan permasalahan sebagai berikut: 1) Adakah perbedaan kemampuan membaca pemahaman siswa SD Negeri 17 Parepare sebelum dan sesudah pembelajaran menggunakan metode Cooperative Script? 2) Bagaimanakah keefektifan penggunaan metode Cooperative Script dalam pembelajaran membaca pemahaman pada siswa kelas V SD Negeri 17 Parepare?

\section{METODE PENELITIAN}

Penelitian ini adalah penelitian ekperimen yang menggunakan pendekatan kuantitatif.. Dikatakan demikian karena metode tersebut digunakan untuk mencari pengaruh perlakuan terhadap yang lain dalam kondisi yang dikendalikan. Perlakuan yang dimaksud adalah penerapan metode Cooperative Script dalam pembelajaran membaca pemahaman pada siswa kelas V SD Negeri 17 Parepare.

Menurut Sugiyono (2011:73) terdapat beberapa bentuk desain eksperimen, yaitu: (1) pre-experimental (nondesign), yang meliputi one-shot case studi, one group pretestposttest, intec-group comparison; (2) true-experimental, meliputi posttest only control design, pretestcontrol group design; (3) factorial experimental; dan (4) Quasi experimental, meliputi time series design dan nonequivalent control group design.

Desain yang digunakan dalam penelitian ini adalah one group pretestposttest design. Dalam desain ini hanya ada satu kelompok/kelas yang terpilih akan diberikan perlakuan berupa pembelajaran menggunakan metode Cooperative Scrift. Sebelum pembelajaran terlebih dahulu diberikan pretest guna mengukur kemampuan dasar responden. Selanjutnya 
setelah pembelajaran dilakukan posttest untuk mengetahui kebermaknaan pembelajaran dengan metode Cooperative
Scrift. Desain penelitian ini digambarkan sebegai berikut:

Tabel 1. Desain Penelitian

\begin{tabular}{|c|c|c|}
\hline $\mathrm{O}_{1}$ & $\mathrm{X}$ & $\mathrm{O}_{2}$ \\
\hline Pretest & Treatmen & Posttest \\
\hline
\end{tabular}

Variabel dalam penelitian terdiri dari dua jenis, yaitu variabel bebas dan variabel terikat. Variabel bebas adalah metode Cooperative Script dalam pembelajaran, sedangkan variabel terikatnya adalah kemampuan membaca pemahaman siswa kelas V SD Negeri 17 Parepare. Populasi dalam penelitian ini adalah keseluruhan siswa kelas V SD Negeri 17 Parepare. Sekolah ini terletak di jantung Kota Parepare Kelurahan Ujung Bulu Kecamatan Ujung. Total siswa pada tahun ajaran 2016/2017 ini adalah 204 orang yang terdiri atas 98 laki-laki dan 106 Perempuan.

Teknik pengumpulan data yang digunakan dalam penelitian ini adalah dengan menggunakan tes. Instrumen yang dipakai adalah tes kemampuan membaca pemahaman berupa tes objektif sebanyak 30 butir soal dengan empat alternatif jawaban. Jika jawaban benar diberi skor 1 dan jika jawaban salah diberi skor 0 . Tes yang diujikan tersebut terdiri atas tes awal (pretest) untuk mengetahui kemampuan awal siswa dan tes kemampuan akhir (posttest) untuk mengetahui kemampuan akhir siswa. Instrumen ini telah disusun dengan berpedoman pada taksonomi Barret dengan lima aspek di dalamnya yaitu, (1) pemahaman harafiah, (2) pemahaman inferensial, (3) mereorganisasi, (4) penilaian, dan (5) apresiasi.

\section{Validitas Penelitian}

Sebelum instrumen tes digunakan dalam penelitian, terlebih dahulu dilakukan uji coba instrumen untuk mengetahui uji validitas dan uji reabilitasnya. Validitas yang digunakan dalam penelitian ini adalah validitas isi (content validity). Tujuan dari validitas isi adalah untuk mengetahui seberapa besar instrumen tersebut telah mencerminkan isi yang dikehendaki. Isi instrumen berpedoman pada taksonomi Barret lalu disesuaikan dengan materi pelajaran bahasa Indonesia dan aspek keterampilan membaca pemahaman.

Untuk mengetahui apakah butir-butir soal yang disusun tersebut layak atau tidak, maka perlu dilakukan analisis butir soal. Dalam penelitian ini, untuk menguji kelayakan suatu butir soal, digunakan bantuan program SPSS 21. Uji coba instrumen dilakukan di sekolah yang lain dengan karakter yang hampir sama dan tingkatan kelas yang sama yaitu kelas V.

\section{Reliabilitas Penelitian}

Reliabilitas penelitian ini dilakukan untuk mengetahui apakah tes dapat mengukur secara konsisten keterampilan membaca pemahaman dari waktu ke waktu. Uji reliabilitas yang digunakan dalam penelitian ini adalah dengan rumus Iteman yang ditunjukkan oleh nilai Alpha Cronbach.

Berdasarkan hasil analisis, dinyatakan bahwa dari 30 butir soal, semua butir soal dinyatakan layak (valid) dan relaibel. Oleh karena itu jumlah butir soal yang dibutuhkan untuk pretest dan posttest sebanyak 30 butir soal yang sama. Dengan demikian, jumlah 30 butir soal yang dinyatakan valid tersebut sudah memenuhi syarat untuk digunakan dalam pretest dan posttest dengan.

Penelitian ini dilaksanakan di SD Negeri 17 Parepare dengan subjek penelitian siswa kelas V pelajaran 2016/2017. Sebelum dilakukan analisis data, dilakukanlah uji prasyarat analisis. Kedua uji prasyarat ini akan dianalisis dengan menggunakan bantuan software SPSS 21 .

a) Uji Normalitas

Uji normalitas berfungsi untuk menguji normal tidaknya data dalam penelitian. Uji normalitas ini diperoleh dari skor pretest dan posttest pada seluruh resonden. Interpretasi hasil uji normalitas dilakukan dengan melihat nilai p. Adapun interpretasi teori uji normalitas sebagai berikut. Jika nilai p lebih besar dari 0,05 , berarti data dari populasi berdistribusi normal. Sebaliknya, jika nilai $p$ kurang dari 0,05 , berarti data dari populasi berdistribusi tidak normal atau menyimpang.

b) Uji Homogenitas

Sementara itu, uji homogenitas dilakukan untuk mengetahui apakah sampel yang dipakai pada penelitian ini diperoleh 
dari populasi yang bervarian homogen atau tidak. Dalam penelitian ini, uji homogenitas dilakukan terhadap skor pretest dan posttest Cara mengujinya menggunakan program SPSS dengan uji statistik test (test of varian). Jika nilai signifikan hitung lebih dari 0,05 , maka hasil tersebut memiliki varian yang homogen.

\section{Uji Analisis Data}

Uji analisis data dimaksudkan untuk menguji perbedaan kemampuan membaca pemahaman sebelum dan sesudah pembelajaran menggunakan metode Script Cooperative . Uji analisis uji-t digunakan untuk menguji apakah nilai rata-rata dari data pretest dan posttest memiliki perbedaan yang signifikan atau tidak. Kriteria pengujian dengan membandingkan nilai $t_{\text {hitung }}$ dan $t_{\text {tabel }}$ pada signifikansi 0,05:2 (uji dua sisi) dengan derajat kebebasan (df) $\mathrm{n}-1$. Jika $-\mathrm{t}$ table $\leq \mathrm{t}$ hitung $\leq \mathrm{t}$ table maka $\mathrm{H}_{0}$ diterima (tidak signifikan). Kriteria lain dapat dilakukan dengan melihat nilai $\mathrm{p}$. Apabila nila $\mathrm{p}$ lebih dari 0,05 , maka $\mathrm{H}_{0}$ diterima (tidak signifikan).

\section{HASIL \& PEMBAHASAN}

Hasil Penelitian

Penelitian ini bertujuan untuk mengetahui perbedaan kemampuan membaca pemahaman siswa kelas V SD Negeri 17 Parepare yang diajar menggunakan metode Cooperative Script dan siswa kelas V SD Negeri 17 yang diajar tanpa menggunakan metode Cooperative Script.Selain itu, penelitian ini bertujuan untuk mengetahui keefektifan metode Cooperative Script dalam pembelajaran membaca pemahaman siswa kelas V SD Negeri 17 Sebelum diberi perlakuan, terlebih dahulu dilakukan tes awal (pretest) yang bertujuan untuk mendapatkan informasi awal antara kemampuan membaca pemahaman kelompok kontrol dan kelompok eksperimen. Kelompok eksperimen yang sudah mendapat perlakuan dengan metode Cooperative Script dan kelompok kontrol yang tidak diberi perlakuan dengan metode Cooperative Script kemudian diberikan tes akhir (posttest) guna mengetahui perbedaan kemampuan membaca pemahaman kedua kelompok tersebut.

Data dalam penelitian ini meliputi data skor tes awal dan data skor tes akhir membaca pemahaman responden disajikan sebagai berikut.

\section{Deskripsi Data}

\section{a. Data Skor Pretest kemampuan Membaca Pemahaman}

Responden dalam kelas ini diajar menggunakan metode Cooperative Script. Sebelum diberi perlakuan, terlebih dahulu dilakukan pretest kemampuan membaca pemahaman berupa tes pilihan ganda berjumlah 30 butir. Distribusi perolehan nilai pretest dapat dilihat pada tabel berikut:

Tabel 2. Distribusi Frekuensi Data Pretest Kelompok Eksperimen

\begin{tabular}{|c|c|c|c|c|c|}
\hline & & Frequency & Percent & Valid Percent & $\begin{array}{l}\text { Cumulative } \\
\text { Percent }\end{array}$ \\
\hline \multirow[t]{13}{*}{ Valid } & 11 & 1 & 2,7 & 2,7 & 2,7 \\
\hline & 12 & 1 & 2,7 & 2,7 & 5,4 \\
\hline & 13 & 2 & 5,4 & 5,4 & 10,8 \\
\hline & 14 & 4 & 10,8 & 10,8 & 21,6 \\
\hline & 15 & 1 & 2,7 & 2,7 & 24,3 \\
\hline & 16 & 7 & 18,9 & 18,9 & 43,2 \\
\hline & 17 & 9 & 24,3 & 24,3 & 67,6 \\
\hline & 18 & 5 & 13,5 & 13,5 & 81,1 \\
\hline & 20 & 3 & 8,1 & 8,1 & 89,2 \\
\hline & 21 & 2 & 5,4 & 5,4 & 94,6 \\
\hline & 23 & 1 & 2,7 & 2,7 & 97,3 \\
\hline & 24 & 1 & 2,7 & 2,7 & 100,0 \\
\hline & Total & 37 & 100,0 & 100,0 & \\
\hline
\end{tabular}

Berdasar tabel 5.1 dapat digambarkan

melalui histogram sebagai berikut. 


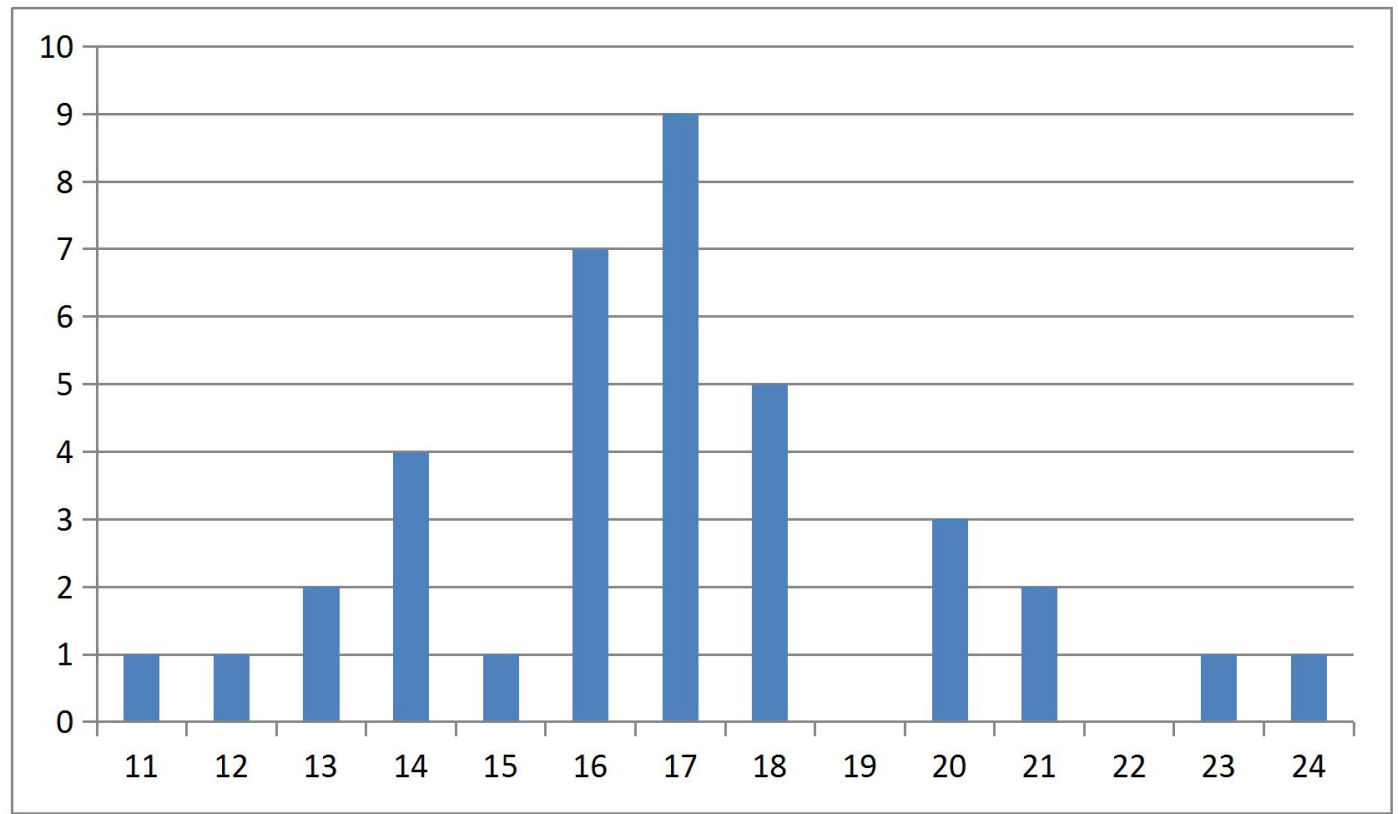

Gambar 1. Histogram data pretest

Berdasarkan tabel dan gambar di atas dapat diketahui bahwa skor tertinggi kemampuan membaca pemahaman siswa sebesar 24 dengan frekuensi 1 dan presentase $2,7 \%$. Sedangkan skor terendahnya sebesar 11 dengan presentase $2,7 \%$. Data skor hasil pretest kemampuan membaca pemahaman masih jauh dari skor maksimal yang ditentukan, yaitu 30. Siswa yang memiliki skor di atas 20 hanya terdapat 7 siswa saja dari 37 siswa. Hal ini menunjukkan bahwa kemampuan siswa masih rendah.

\section{b. Data Skor Posttest Kemampuan Membaca Pemahaman}

Pemberian posttest kemampuan membaca pemahaman dimaksudkan untuk melihat perbedaan kemampuan membaca pemahaman sesuda diberikan perlakuan berupa pengajaran menggunakan metode Cooperative Script. Data hasil posttest diperoleh skor tertinggi 29, sedangkan skor terendah 14.. Hasil perhitungan skor posttest selengkapnya dapat dilihat pada table berikut:

Tabel 3. Distribusi Frekuensi Data Posttest

\begin{tabular}{|c|c|c|c|c|c|}
\hline & & Frequency & Percent & Valid Percent & $\begin{array}{l}\text { Cumulative } \\
\text { Percent }\end{array}$ \\
\hline \multirow[t]{13}{*}{ Valid } & 14 & 1 & 2,7 & 2,7 & 2,7 \\
\hline & 16 & 2 & 5,4 & 5,4 & 8,1 \\
\hline & 17 & 1 & 2,7 & 2,7 & 10,8 \\
\hline & 18 & 1 & 2,7 & 2,7 & 13,5 \\
\hline & 22 & 2 & 5,4 & 5,4 & 18,9 \\
\hline & 23 & 5 & 13,5 & 13,5 & 32,4 \\
\hline & 24 & 9 & 24,3 & 24,3 & 56,8 \\
\hline & 25 & 3 & 8,1 & 8,1 & 64,9 \\
\hline & 26 & 1 & 2,7 & 2,7 & 67,6 \\
\hline & 27 & 4 & 10,8 & 10,8 & 78,4 \\
\hline & 28 & 7 & 18,9 & 18,9 & 97,3 \\
\hline & 29 & 1 & 2,7 & 2,7 & 100,0 \\
\hline & Total & 37 & 100,0 & 100,0 & \\
\hline
\end{tabular}

Berdasarkan di atas dapat diketahui bahwa skor tertinggi kemampuan membaca pemahaman siswa setelah perlakuan sebesar 29 dengan frekuensi 1 dan presentase $2,7 \%$. Sedangkan skor terendahnya sebesar 14 dengan presentase 2,7\%. Data skor hasil postest kemampuan membaca pemahaman ini sudah menunjukkan peningkatan yang signifikan dan sebanyak 33 orang atau $89,1 \%$ dari seluruh responden mencapai skor di atas 
20. Grafik histogram dari data posttest di atas

dapat dilihat pada gambar berikut:

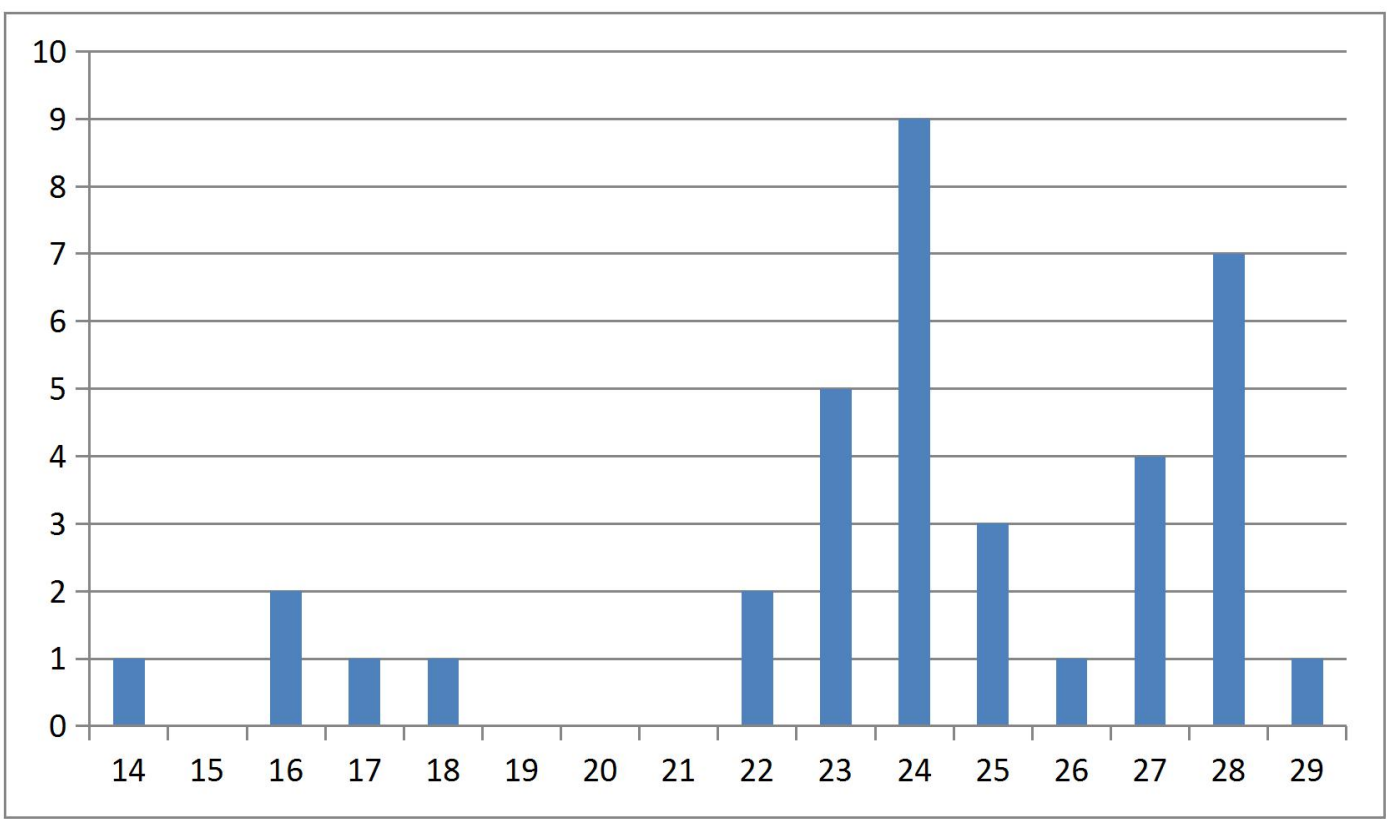

Grafik 2. Histogram data post test

Data tentang ukuran pemusatan berupa

tabel berikut ini: mean, median dan modus dapat dilihat pada

Tabel 4. Ukuran pemusatan data pretest dan post test

\begin{tabular}{lccc}
\hline & & pretest & posttest \\
\hline \multirow{2}{*}{$\mathrm{N}$} & Valid & 37 & 37 \\
\cline { 2 - 4 } & Missing & 0 & 0 \\
\hline Mean & 16,86 & 24,05 \\
\hline Median & 17,00 & 24,00 \\
\hline Mode & 17 & 24 \\
\hline Std. Deviation & 2,830 & 3,749 \\
\hline Skewness &, 386 & $-1,112$ \\
\hline Std. Error of Skewness &, 388 &, 388 \\
\hline Minimum & 11 & 14 \\
\hline Maximum & 24 & 29 \\
\hline
\end{tabular}

Tabel di atas menunujukkan bahwa nila rata-rata sebelum dan sesudah perlakuan menunjukkan peningkatan, yakni dari 16,86 menjadi 24,06 . Nilai modus pada skor pretest adalh 17 sedangkan pada post test adalah menjadi 24. Demikian pula standar deviasi sebelum perlakuan sebesar 2,830 dan setelah perlakuan berubah menjadi 3,749.

2. Hasil Uji Prasyarat Analisis

a. Hasil Uji Normalitas

Data pada uji normalitas ini diperoleh dari pretest dan posttest baik pada kelompok kontrol maupun pada kelompok eksperimen. Pengujian data ini menggunakan bantuan program komputer SPSS 21 dengan melihat nilai signifikansi yang dapat menunjukkan sebaran data berdistribusi normal atau tidak. Syarat data dikatakan berdistribusi normal apabila nilai $p$ yang diperoleh dari hasil perhitungan lebih besar dari syarat signifikansi, yaitu sebesar 0,05 . Berikut disajikan tabel hasil perhitungan uji normalitas 
Tabel 5. Hasil Uji Normalitas

One-Sample Kolmogorov-Smirnov Test

\begin{tabular}{llrr}
\hline & & pretest & posttest \\
\hline $\mathrm{N}$ & & 37 & 37 \\
\hline Normal Parameters & & 16,86 & 24,05 \\
& Mean & 2,830 & 3,749 \\
\cline { 2 - 4 } Most Extreme & Std. Deviation &, 157 &, 200 \\
Differences & Absolute &, 157 &, 119 \\
\cline { 2 - 4 } & Positive &,- 137 &,- 200 \\
\cline { 2 - 4 } & Negative &, 157 &, 200 \\
\hline Test Statistic & &, $222^{\mathrm{c}}$ &, $111^{\mathrm{c}}$ \\
\hline Asymp. Sig. (2-tailed) & & & \\
\hline
\end{tabular}

a. Test distribution is Normal.

b. Calculated from data.

c. Lilliefors Significance Correction.

Dari uji data di atas, terlihat bahwa distribusi datanya adalah normal. Hal ini terlihat dari data dikatakan berdistribusi normal jika nilai signifikansi yang dihasilkan lebih dari 0,05 .

b. Hasil Uji Homogenitas Varian

Uji homogenitas varian dimaksudkan untuk mengetahui apakah sampel yang diambil dari populasi memiliki varian yang sama dan tidak menunjukkan perbedaan yang signifikan satu sama lain.
Syarat data dikatakan bersifat homogen jika kesalahan hitung lebih besar dari derajat kesalahan yaitu $0,05 \quad(5 \%)$. Uji homogenitas dilakukan terhadap data tes awal (pretest) dan tes akhir (posttest) pada kelompok eksperimen dan kelompok kontrol. Proses perhitungan dilakukan dengan bantuan program komputer SPSS 21 . Berikut disajikan tabel hasil perhitungan uji homogenitas.

Tabel 6. Rangkuman Hasil Uji Homogenitas

Test of Homogeneity of Variances

\begin{tabular}{rrrr}
\hline Levene Statistic & df1 & \multicolumn{1}{c}{ df2 } & Sig. \\
\hline 3,022 & 6 & 25 &, 123 \\
\hline
\end{tabular}

Tabel 4.5 di atas menunjukkan bahwa nilai signifikansi $p>0,05(0,123>$ $0,05)$. Jadi dapat disimpulkan bahwa varian antara data kelompok pretest dan kelompok post test adalah sama. Hal ini telah memenuhi asumsi dasar homogenitas.

\section{Hasil Analisis Data}

Analisis data pada penelitian ini bertujuan untuk mengetahui perbedaan yang signifikan kemampuan membaca pemahaman antara siswa yang mengikuti pembelajaran dengan menggunakan metode Cooperative Script dengan siswa yang mengikuti pembelajaran tanpa menggunakan metode Cooperative Script di SD Negeri 17 Parepare. Analisis data yang digunakan adalah uji-t. Teknik analisis ini digunakan untuk menguji apakah skor pretest dan posttest memiliki perbedaan yang signifikan. Perhitungan uji-t dilakukan dengan bantuan SPSS 21. Syarat dikatakan berbeda secara signifikan apabila nilai $\mathrm{p}$ lebih kecil dari taraf signifikansi 0,05 .

a. Uji-t Data Skor Pretest dan Posttest Uji-t data pretest dan posttest dilakukan untuk mengetahui perbedaan yang signifikan kemampuan membaca pemahaman dengan menggunakan metode Cooperative Script sebelum dan sesuadah pembelajaran. Rangkuman hasil uji-t data pretest dan posttest dapat dilihat pada tabel sebagai berikut:

Tabel 7. Hasil uji-t Pretes dan postest

\begin{tabular}{cllcc}
\hline Data & $\mathrm{t}_{\text {hitung }}$ & $\mathrm{db}$ & $p$ & keterangan \\
\hline Pretest-postest & $-24,829$ & 36 & 0.000 & $\mathrm{P}<0,05=$ signifikan \\
\hline
\end{tabular}

Tabel hasil Uji-t data pretest dan posttest menunjukkan bahwa hasil thitung sebesar $-24,829$ dengan $\mathrm{db}=36$, dan nilai $\mathrm{p}$ sebesar 0,000 . Nilai $\mathrm{p}$ lebih kecil dari taraf 
signifikansi sebesar $0,05(0.000<0,05)$, berarti $\mathrm{H}_{0}$ ditolak atau $\mathrm{H}_{1}$ diterima

b. Hasil Uji Hipotesis

Setelah dilakukan analisis data menggunakan uji-t, kemudian dilakukan uji hipotesis. Berdasarkan hasil uji-t, maka dapat disimpulkan bahwa:

$$
\begin{aligned}
& \mathrm{H}_{0}: \mu_{1}=\mu_{2} \text { (ditolak) } \\
& \mathrm{H}_{1}: \mu_{1}>\mu_{2} \text { (diterima) }
\end{aligned}
$$

Dari informasi statistik deskriptif dan uji hipotesis di atas dapat disimpulkan bahwa: 1) Terdapat perbedaan kemampuan membaca pemahaman siswa kelas V SD 17 Parepare sebelum dan sesudah pembelajaran menggunakan metode Cooperative Scrift. 2) Metode pengajaran Cooperative Scrift efektif digunakan dalam pengajaran membaca pemahaman pada siswa kelas V SD Negeri 17 Parepare.

\section{B. Pembahasan Hasil Penelitian}

Kondisi awal kemampuan membaca pemahaman dilihat dengan menggunakan pretest kemampuan membaca pemahaman pada semua responden. Siswa diminta untuk mengerjakan tes awal kemampuan membaca pemahaman untuk melihat kemampuan awal siswa sebelum diberi perlakuan. Dari hasil skor pretest tersebut diketahui bahwa skor rata-rata pada pretest, yaitu 16,56. Oleh karena itu, dari hasil perhitungan tersebut, dapat dikatakan bahwa kemampuan membaca pemahaman siswa berada pada kategori rendah (skor maksimal 30). Hal ini berkaitan dengan kondisi pembelajaran membaca yang jika belum mendapat perlakuan akan tetap seperti semula yang mengalami hambatan juga kesulitan dalam membaca.

Setelah mengetahui skor awal (pretest), kemudian diberi perlakuan berupa pembelajaran dengan menggunakan metode Cooperative Script. Perlakuan diberikan sebanyak dua kali. Setelah selesai, dilakukan posttest kemampuan membaca pemahaman berupa soal yang sama pada saat pretest, baik dari segi jumlah maupun dari segi kulaitas soal.. Posttest bertujuan untuk mengetahui apakah terdapat perbedaan kemampuan membaca pemahaman sebelum dan sesuadah diberi perlakuan berupa pembelajaranmenggunakan metode Cooperative Script. Setelah mendapatkan pembelajaran membaca pemahaman dengan metode Cooperative Script, responden mengalami peningkatan yang baik. Hasil tersebut dapat diketahui dari skor rata-rata kemampuan membaca pemahaman pada posttest mengalami kenaikan menjadi 24,05. Artinya, Skor rata-rata reponden kini berada dalam kategori baik.

Perbedaan kemampuan membaca sebelum dan sesudah perlakuan juga ditunjukkan dari hasil analisis uji-t. Hasil analisis uji-t data pretest dan pos test diperoleh sebesar $-24,829$ dengan $\mathrm{db}=36$, nilai $\mathrm{p}$ sebesar 0,000 . Nilai $\mathrm{p}$ lebih kecil dari pada taraf signifikansi $0,05(0,000<0,05)$ artinya signifikan. Dengan demikian, hasil uji-t tersebut menunjukkan terdapat perbedaan kemampuan membaca pemahaman setelah diberi perlakuan kepada responden

Keberhasilan pembelajaran membaca pemahaman menggunakan metode Cooperative Script dapat dikaitkan dengan teori. Proses pembelajaran membaca pemahaman menggunakan metode Cooperative Script terdiri dari lima langkah utama, yaitu membentuk kelompok, membaca, berdiskusi, presentasi dan refleksi dari guru. Metode Cooperative Script merupakan metode belajar secara bersama (kooperatif) dengan peserta didik yang lain dalam sebuah kelompok. Sesuai dengan teori Vygotsky (dalam Suprijono, 2009:56) yang menekankan pentingnya sebuah pembelajaran kooperatif adalah arti penting belajar kelompok. Pembelajaran dalam kelompok juga meningkatkan pengubahan secara konseptual, sehingga keterlibatan dengan orang lain membuka kesempatan bagi peserta didik untuk mengevaluasi dan memperbaiki pemahaman mereka, Suprijono (2009:39). Hal tersebut yang mendasari mengapa dalam pembelajaran Cooperative Script ini dilakukan dengan pembentukan kelompok.

Langkah selanjutnya adalah kegiatan membaca. Membaca merupakan salah satu cara yang umum digunakan untuk dapat memahami suatu bacaan. Pada tahap membaca ini, siswa akan menandai bagian-bagian yang penting dalam teks bacaan, sehingga memudahkan siswa untuk lebih memahami maksud bacaan dengan baik. Hal ini sesuai dengan pendapat Zuchdi (2008:81) yang menyatakan bahwa untuk dapat menemukan ide-ide penting dan memahami bacaan dilakukan dengan cara menandai bagian-bagian yang penting.

Setelah membaca, tahap selanjutnya adalah diskusi. Dalam diskusi ini, siswa diminta untuk dapat membuat sebuah script yang berisi ringkasan-ringkasan mengenai ide 
pokok setiap paragraf. Zuchdi (2008:79) menungkapkan bahwa meringkas merupakan salah satu latihan yang cocok digunakan untuk dapat lebih memahami ide pokok suatu cerita/bacaan. Langkah keempat adalah presentasi. Marpaung (dalam Winarno, 2009:3) menyatakan bahwa presentasi merupakan strategi penyajian perangkat bahan ajar oleh fasilitator kepada seorang atau sekelompok peserta dalam bentuk kegiatan pembelajaran terprogram. Presentasi dalam metode Cooperative Script dilakukan oleh kelompok pembaca terlebih dahulu, kemudian kelompok pendengar akan memberikan koreksi dari hasil presentasi kelompok pembaca.

Selanjutnya, dilakukan refleksi pembelajaran oleh guru. Refleksi dimaksudkan sebagai upaya untuk melihat kembali, mengorganisir kembali, menganalisis kembali, mengklarifikasi kembali, dan mengevaluasi hal-hal yang telah dipelajari. Suprijono (2009:52) menyatakan bahwa refleksi berupa rangkuman apa yang telah dipelajari peserta didik selama dan menjelang akhir pelajaran. Guru mengoreksi kesalahpahaman dan menarik kesimpulan, poin-poin serta ide-ide kunci.

Tahap-tahap dalam pembelajaran membaca pemahaman menggunakan metode ini sesuai dengan pengertian yang dinyatakan Suprijono (2009) bahwa metode Cooperative Script merupakan metode belajar di mana siswa bekerja berpasangan dan bergantian secara lisan mengikhtisarkan, bagian-bagian dari materi yang dipelajari. Hasil penelitian dengan langkah-langkah yang telah diuraikan di atas terbukti membantu siswa untuk dapat lebih memahami informasi dalam bacaan.

Proses pembelajaran dengan menggunakan metode Cooperative Script lebih aktif dibanding dengan proses pembelajaran membaca pemahaman menggunakan pembelajaran biasa. Pada proses pembelajaran seluruh siswa aktif berdiskusi untuk dapat memecahkan masalah. Hal ini terbukti dengan banyaknya siswa yang aktif mengemukakan pendapat di dalam masing-masing kelompok untuk dapat menemukan letak kalimat utama dan gagasan utama dalam setiap paragraf yang ada dalam bacaan. Selain aktif mengemukakan masing-masing pendapat, pada saat dilakukan presentasi, di mana wakil dari setiap pasangan kelompok pembaca akan membacakan hasil diskusi mereka, kelompok pendengar juga terbukti dapat menambahkan ideide/mengomentari kekurangan dari kelompok pembaca. Siswa juga dapat menjadi lebih percaya diri dan berani untuk dapat mengemukakan kesalahan dan lebih teliti dalam memahami suatu bacaan. Berdasarkan gambaran pembelajaran membaca pemahaman menggunakan metode Cooperative Script di atas, terlihat bahwa pembelajaran membaca pemahaman kelompok eksperimen lebih bersifat aktif.

Hasil dari penelitian ini menujukkan bahwa metode Cooperative Script teruji dapat bermanfaat bagi siswa dalam proses pembelajaran membaca pemahaman sehingga terjadi peningkatan kemampuan membaca pemahaman. Manfaat yang diperoleh siswa kelompok eksperimen ditunjukkan oleh beberapa hal, di antaranya adalah aktif mengemukakan masing-masing pendapat pada saat dilakukan presentasi, di mana wakil dari setiap pasangan kelompok pembaca akan membacakan hasil diskusi mereka, kelompok endengar juga terbukti dapat menambahkan ide-ide/mengomentari kekurangan dari kelompok pembaca. Siswa juga dapat menjadi lebih percaya diri dan berani untuk dapat mengemukakan kesalahan dan lebih teliti dalam memahami suatu bacaan.

Berbeda dengan pembelajaran tanpa menggunakan metode Cooperative Script, siswa lebih banyak diam dari pada bertanya mengenai kesulitan yang ditemukan dalam bacaan. Kegiatan siswa pada kelompok kontrol hanya memperoleh bacaan kemudian membacanya dan menjawab soal yang diberikan oleh gurunya. Pembelajaran yang sedemikian itu menjadi kurang menarik bagi siswa sehingga siswa merasa jenuh untuk mengikuti pembelajaran. Pembelajaran di kelompok kontrol juga terlihat pasif.

Dari penjelasan di atas terlihat terdapat perbedaan kemampuan membaca pemahaman menggunakan metode Cooperative Script dengan pembelajaran konvesional yang menggunakan pembelajaran secara biasa menggunakan metode ceramah. Hal ini menunjukkan bahwa tujuan penelitian sudah tercapai.

Metode Cooperative Script ini merupakan metode yang efektif digunakan dalam meningkatkan kemampuan membaca pemahaman siswa. Dengan adanya metode ini, siswa akan lebih mudah untuk memahami setiap teks yang dibacanya dengan bantuan script yang mereka buat. 
Keefektifan metode Cooperative Script pada kelompok eksperimen dapat diketahui dengan uji-t. hasil analisis uji-t menunjukkan bahwa data tersebut signifikan. Nilai sebesar $-24,829$ dengan $\mathrm{db}=36$, nilai $\mathrm{p}$ sebesar 0,000 . Nilai $p$ lebih kecil dari pada taraf signifikansi $0,05(0,000<0,05)$ artinya signifikan. Dengan demikian, terdapat perbedaan hasil kemampuan membaca pemahaman yang lebih sebelum dan sesudah perlakuan. Dengan kata lain, metode Cooperative Script lebih efektif digunakan untuk pembelajaran membaca pemahaman.

Keefektifan metode ini juga dapat dilihat dalam proses pembelajaran. Hasil peningkatan dapat dilihat dari ketepatan siswa menemukan gagasan utama dan menentukan letak kalimat utama. Hasil dari penelitian ini sesuai dengan tujuan dari metode Cooperative Script yaitu untuk menjadikan siswa lebih baik memahami materi bacaan. Pembelajaran dengan metode Cooperative Script membuat siswa lebih teliti dan runtut dalam memahami bacaan berdasar script yang telah dibuat. Kelompok eksperimen yang mengikuti pembelajaran dengan menggunakan metode Cooperative Script memiliki antusias yang tinggi dalam proses pembelajaran, kondisi tersebut mempengaruhi tingkat pencapaian pemahaman siswa terhadap bacaan.

Tingkat keefektifan penggunaan metode Cooperative Script dalam pembelajaran membaca pemahaman di SD Negeri 17 Parepare dapat diketahui dari kenaikan skor rata-rata pretest dan posttest. Proses pembelajaran membaca pemahaman menggunakan metode Cooperative Script berjalan efektif. Keberhasilan tersebut dibuktikan dengan adanya kemampuan mengarahkan perhatian siswa pada hal-hal tertentu terkait dengan bacaan. Kemampuan membuat siswa menjadi lebih aktif dalam mengemukakan pendapat tentang konsep yang didiskusikan terkait dengan bacaan.

Hasil penelitian ini sesuai dengan tujuan penelitian yaitu untuk mengetahui perbedaan kemampuan membaca pemahaman kelompok eksperimen dengan kelompok kontrol serta untuk mengetahui keefektifan penggunaan metode Cooperative Script dalam pembelajaran membaca pemahaman di SD Negeri 17 Parepare

\section{KESIMPULAN \& SARAN}

telah diuraikan dalam bab sebelumnya, dapat disimpulkan sebagai berikut: 1) Terdapat perbedaan yang signifikan antara kemampuan membaca pemahaman siswa kela V SD Negeri 17 Parepare sebelum dan sesudah mengikuti pembelajaran dengan menggunakan metode Cooperative Script. 2) Pembelajaran membaca pemahaman dengan menggunakan metode Cooperative Script lebih efektif dibandingkan dengan pembelajaran membaca pemahaman yang menggunakan metode konvensional.

Hasil penelitian menunjukkan bahwa pembelajaran membaca pemahaman menggunakan metode Cooperative Script lebih efektif dibandingkan dengan metode ceramah. Hal tersebut berimplikasi secara teoritis dan praktis. Secara teoritis, penelitian ini memberikan bukti tentang keefektifan metode Cooperative Script. Secara praktis, hasil penelitian ini telah membuktikan bahwa pembelajaran membaca pemahaman dengan menggunakana metode Cooperative Script lebih efektif dibandingkan dengan metode ceramah, sehingga dapat dipergunakan untuk meningkatkan kemampuan siswa.

Berdasarkan kesimpulan dan implikasi di atas dapat disarankan beberapa hal sebagai berikut.1) Guru diharapkan dapat menggunakan dan menerapkan metode pembelajaran terbaru. Hal ini bertujuan agar siswa tidak jenuh dalam proses pembelajaran khususnya materi membaca pemahaman. Variasi metode sangat dianjurkan agar proses pembelajaran tidak berlangsung monoton. 2) Guru hendaknya dapat menggunakan metode Cooperative Script dalam pembelajaran membaca pemahaman dengan didampingi media yang tepat. 3) Siswa SD Negeri 17 Parepare diharapkan agar lebih giat meningkatkan kemampuan membaca khususnya membaca pemahaman dengan menerapkan metode Cooperative Script.

\section{DAFTAR PUSTAKA}

Andriani, Yuli. 2012. "Meningkatkan Kemampuan Membaca Anak Melalui Penenggelaman Keaksaraan". Jurnal Kependidikan. Diunduh dalam http://yuli26andriani.blogspot.com/2012/0 4/jurnal-bahasa-indonesia/

Arikunto, Suharsimi. 2012. Prosedur Penelitian Suatu Pendekatan Praktik. Jakarta: Rineka Cipta. 
Burns, Paul C., dkk. 2013. Teaching Reading in Today's Elementary School. Boston : Houghton Mafflin Co. (edition $4^{\text {th }}$ )

Damayanti, Deni. 2010. Keefektifan "Prosedur Bertanya" dalam Meningkatkan Kemampuan Membaca Komprehensi Siswa Kelas XI SMA Negeri 3 Bantul. Skripsi S1. Yogyakarta. Program Studi Pendidikan Bahasa Indonesia. Fakultas Bahasa dan Seni, Universitas Negeri Yogyakarta.

Djaali, H., dan Pudji Muljono. 2008. Pengukuran dalam Bidang Pendidikan.

Jakarta: Gramedia Widiasarana Indonesia.

Nurgiyantoro, Burhan. 2012. Penilaian pembelajaran Bahasa Berbasis Kompetensi. Yogyakarta: BPFEYogyakarta.

Permen 23 tahun 2015, tentang Penumbuhan Budi Pekerti

Priyato, Dwi. 2014. SPSS 21 Pengolah Data terpraktis. Yogyakarta: ANDI

Sanjaya, Wina. 2012. Strategi Pembelajaran Berorientasi Standar Proses Pendidikan. Jakarta : Kencana. (edisi 4)

Shidiq 2008. Meningkatkan Kemampuan Memahami Bacaan Murid Kelas V SDN 1 Wakinamboro Kecamatan Siompu dalam Pelajaran Bahasa Indonesia melalui Cooperative Script. Skripsi S1. Makassar. Program Studi Pendidikan Guru Sekolah Dasar. Fakultas Ilmu Pendidikan. Universitas Negeri Makassar.

Sumarwati, Purwadi. 2010. Pembuatan Pertanyaan Awal Pada Kegiatan Prabaca untuk Meningkatkan Kemampuan Membaca Intensif. Diksi. Vol 17 No 1, 2010. Tanggal 15 Juli 2013

Suprijono, Agus. 2009. Cooperative Learning Teori \& Aplikasi PAIKEM. Yogyakarta: Pustaka Pelajar. (edisi 4:revisi)

Vani, Octaviany . 2013. Kefektifan Metode Pembelajaran Scrift Dalam Pembelajaran Membaca Pemahaman Siswa Kelas VII SMP Negeri 1 Manisrengo. Tesis S2. Yogyakarta. Fakultas Bahasa dan Seni. Universitas Negeri Yogyakarta.

Zuchdi, Darmiyati. 2013. Strategi Meningkatkan Kemampuan Membaca. Yogyakarta: UNY Press. (edisi revisi) 